\title{
Toxicological Characterization of Ten Medicinal Plants of the Beninese Flora Used in the Traditional Treatment of Diarrheal Diseases
}

\author{
Tamègnon Victorien Dougnon ${ }^{\mathbb{D}},{ }^{1}$ Edna Hounsa, ${ }^{1}$ Eric Agbodjento, ${ }^{1}$ Hornel Koudokpon, ${ }^{1}$ \\ Boris Legba, ${ }^{1}$ Kafayath Fabiyi, ${ }^{1}$ Anny Afaton, ${ }^{1}$ Kévin Sintondji, ${ }^{1}$ Benoît Akpode, ${ }^{1}$ \\ Jean Robert Klotoé $\mathbb{C D}^{1},{ }^{1}$ Fidèle Tchobo ${ }^{(D)},{ }^{2}$ Honoré Bankole, ${ }^{1}$ and Tossou Jacques Dougnon ${ }^{1}$ \\ ${ }^{1}$ Research Unit in Applied Microbiology and Pharmacology of Natural Substances, Laboratory of Research in Applied Biology, \\ University of Abomey-Calavi, 01 P.O. Box 2009, Cotonou, Benin \\ ${ }^{2}$ Training and Research Laboratory in Applied Chemistry, Polytechnic School of Abomey-Calavi, University of Abomey-Calavi, \\ Abomey-Calavi, Benin
}

Correspondence should be addressed to Tamègnon Victorien Dougnon; victorien88@hotmail.com

Received 22 October 2020; Revised 12 March 2021; Accepted 25 March 2021; Published 29 April 2021

Academic Editor: Armando Zarrelli

Copyright (c) 2021 Tamègnon Victorien Dougnon et al. This is an open access article distributed under the Creative Commons Attribution License, which permits unrestricted use, distribution, and reproduction in any medium, provided the original work is properly cited.

\begin{abstract}
The use of medicinal plants in traditional medicine is a common practice in developing countries. However, this unregulated or poorly rational use may present a dose-dependent risk of toxicity to humans. This study aimed to explore the phytochemical and toxicological characteristics of ten (10) plant species used in the traditional treatment of infectious diarrhea in Benin. The acute toxicity of aqueous and hydroethanolic extracts of Khaya senegalensis, Daniellia oliveri, Rauvolfia vomitoria, Vernonia amygdalina, Manihot esculenta, Ocimum gratissimum, Senna italica, Diospyros mespiliformis, Pterocarpus erinaceus, and Anacardium occidentale was evaluated following the OECD 423 protocol at a single dose of $2000 \mathrm{mg} / \mathrm{kg}$. This safety test was complemented by a larval cytotoxicity test. Hematological and biochemical examinations, as well as a histological study of the liver and kidneys, were performed. Larval cytotoxicity was assessed by the sensitivity of Artemia salina larvae to different concentrations of the plant extracts studied. Testing for chemical compounds was performed on the basis of differential staining and precipitation reactions. The mean lethal concentration $\left(\mathrm{LC}_{50}\right)$ was determined by the probit method. The qualitative phytochemical screening of the plants studied revealed the presence of catechic tannins, gallic tannins, flavonoids, anthocyanins and sterol-terpenes, alkaloids, saponosides, and reducing compounds. This composition varied according to the plants studied. Acute toxicity data indicated that there was no mortality and no structural and functional alterations of the liver and kidneys of treated animals. Larval cytotoxicity data suggest that the plants studied are not cytotoxic $\left(\mathrm{LC}_{50 \geq} 0.1 \mathrm{mg} / \mathrm{mL}\right)$. These observations reflect the safety of these plants and justify their use in traditional medicine in the treatment of many diseases including diarrheal diseases.
\end{abstract}

\section{Introduction}

Traditional medicine based on the use of medicinal plants is the first reflex of more than $80 \%$ of the world's population for primary health care [1-3]. In developing countries such as Benin, this widely accepted trend is an ancestral medical practice that is transmitted from generation to generation $[4,5]$. The real effectiveness, accessibility, and low cost of medicinal recipes are the main reasons for the perpetuation of this endogenous practice $[6,7]$. The plants used in the African pharmacopeia are directed against several diseases, particularly infectious ones. The prevalence of these infectious diseases is essentially linked to factors such as precarious water quality, unsanitary conditions, and poor food hygiene that are common to most developing countries $[8,9]$. Diarrheal diseases are among the most deadly infectious diseases, particularly among children. In fact, every year, it is estimated that there are 2.5 billion cases of diarrhea 
in children under the age of five [10]. Ugboko et al. [11] reported that childhood diarrhea affecting children five years old and below accounts for approximately $63 \%$ of the global diarrhea burden. $15 \%$ of these children die [12].

Benin is one of the developing countries in which diarrhea diseases are one of the main causes of morbidity $[13,14]$. Indeed, they have a direct impact on the costs associated with seeking health care, including several factors such as consultation, medication, and, in some cases, hospitalization which represents a burden on household expenditures [15]. The pathogens of diarrheal diseases are mainly bacteria [16]. Over the years, medical therapy based on the use of conventional antibiotics has shown not only its effectiveness but also its limitations. Indeed, most bacteria responsible for diarrheal episodes develop resistance to the antibiotics used in therapy.

The phenomenon of multiresistance is today a real public health problem for the effective management of infectious diseases. This problem of bacterial resistance combined with the cost and sometimes difficult access to antibiotics by populations reinforces the use of herbal remedies by these populations. World Health Organization has supported this idea by launching a diarrheal disease control program based on traditional medicine practices and prevention approaches [17]. This can have valuable benefits in reducing child mortality rates in developing countries. In several African pharmacopeias, several ethnobotanical studies have provided information on the richness of African flora in the traditional management of diarrheal diseases [18-20]. Benin, a West African country, has a great floristic diversity to which is added a centuries-old traditional use of plants with unsuspected therapeutic virtues. Akoegninou et al. [21] estimated the ethnobotanical potential of Benin's flora at 2807 plant species. Khaya senegalensis, Daniellia oliveri, Rauvolfia vomitoria, Vernonia amygdalina, Manihot esculenta, Ocimum gratissimum, Senna italica, Diospyros mespiliformis, Pterocarpus erinaceus, and Anacardium occidentale are some of the medicinal plants of the Beninese flora used in the traditional treatment of diarrheal diseases. These plants are also used in the traditional treatment of other diseases. For example, Khaya senegalensis, Ocimum gratissimum, Daniellia oliveri, and Manihot esculenta are used in the traditional treatment of metabolic diseases such as diabetes and blood disorders such as anemia [22-25]. The therapeutic virtues of these medicinal plants are attributed to secondary metabolites such as saponosides, flavonoids, coumarins, tannins, alkaloids, mucilages, volatile compounds, sterols, and terpenes identified in different parts of these plants [26]. However, despite the widespread use of traditional herbal remedies in the treatment of diarrheal diseases, very few scientific studies exist at this stage on the safety of antidiarrheal plants. It is, therefore, important, if not essential, to explore the toxicological characteristics of the main plants used by local communities in several African pharmacopeias in order to secure their use in traditional medicine. This study was initiated to produce recent data on the toxicological characteristics of selected plants as used in traditional medicine. It aimed to evaluate the larval cytotoxicity and acute toxicity of aqueous and hydroethanolic extracts of the selected plants on Wistar albino rats to predict their safety in the human species.

Rats are recommended lower-level animals for toxicity studies to extrapolate to human biology according to Organization for Economic Cooperation and Development (OECD) safety study guidelines [27, 28]. The finding of the study could also help to guide the optimization and validation of the traditional use of these antidiarrheal plants.

\section{Materials and Methods}

2.1. Plant Material. The plant material used in this study consists of plant organs from 10 medicinal plants used in the traditional treatment of diarrheal diseases in Benin (Table 1). These organs were harvested in various regions of Benin according to the indications of practitioners of traditional medicine. The plant samples once collected were authenticated at the National Herbarium of Benin using the analytical flora of Akoegninou et al. [21]. The botanical nomenclature of The PlantList available on the website http://www. ThePlantList.com has been used to confirm this identification.

2.2. Animal Material. The animal material consisted of eggs of Artemia salina and albino Wistar rats. Eggs of Artemia salina (ARTEMIO JBL D-67141 Gmbh Neuhofem) were used for the larval cytotoxicity test of selected medicinal plants. Three-month-old Wistar albino rats weighing between 130 and $180 \mathrm{~g}$, all nonpregnant and female, from the pet shop of the Institute of Applied Biomedical Sciences (ISBA) of the University of Abomey-Calavi were used for acute toxicity testing. Upon receipt, the rats were randomly assigned to groups of 3 in standard cages for a 2-week acclimatization period in the Research Unit in Applied Microbiology and Pharmacology of natural substances of the University of Abomey-Calavi prior to use. During this period, the animals had free access to food and water. Animal Research Review Panel and Animal Welfare Unit regulation of temperature and lighting systems was maintained with a room temperature of $20-26^{\circ} \mathrm{C}$ as well as regular light cycles of 12 hours light/dark. All methods and protocols used in this study were observed following established public health guidelines "Guide for Care and Use of Laboratory Animals" [29].

2.3. Phytochemical Analysis. A qualitative phytochemical screening carried out according to the method based on precipitation and staining reactions described by Houghton and Raman [30] made it possible to detect the presence or absence of large chemical groups in the organs of the selected plants. These searched chemical groups were tannins, gallic tannins, flavonoids, anthocyanins, leucoanthocyanins, alkaloids, mucilages, reducing compounds, sterols, terpenes, and saponosides.

2.4. Extracts Production. Samples collected of the selected plants were cleaned with tap water and then dried at ambient 
TABLE 1: Information about in the selected medicinal plants.

\begin{tabular}{|c|c|c|c|c|c|}
\hline $\begin{array}{l}\text { Identification } \\
\text { number }\end{array}$ & Scientific name & Botanical family & $\begin{array}{l}\text { Used } \\
\text { part }\end{array}$ & $\begin{array}{c}\text { Collection area } \\
\text { (municipality) }\end{array}$ & $\begin{array}{l}\text { Collection } \\
\text { period }\end{array}$ \\
\hline YH $434 / \mathrm{HNB}$ & Anacardium occidentale L. & Anacardiaceae & Leaves & Abomey-Calavi & July 2020 \\
\hline YH 436/HNB & $\begin{array}{c}\text { Daniellia oliveri (Rolfe) Hutch. \& } \\
\text { Dalziel }\end{array}$ & Leguminosae & Leaves & Toffo & July 2020 \\
\hline YH $438 / \mathrm{HNB}$ & $\begin{array}{c}\text { Diospyros mespiliformis Hochst. ex } \\
\text { A. DC. }\end{array}$ & Ebenaceae & Leaves & Toffo & July 2020 \\
\hline YH 435/HNB & Khaya senegalensis (Desr.) A. Juss. & Meliaceae & Bark & Abomey-Calavi & July 2020 \\
\hline YH $442 / \mathrm{HNB}$ & Manihot esculenta Crantz & Euphorbiaceae & Leaves & Abomey-Calavi & July 2020 \\
\hline YH $437 / \mathrm{HNB}$ & Ocimum gratissimum L. & Lamiaceae & Leaves & Abomey-Calavi & July 2020 \\
\hline YH $440 / \mathrm{HNB}$ & Pterocarpus erinaceus Poir. & Euphorbiaceae & Leaves & Toffo & July 2020 \\
\hline YH $441 / \mathrm{HNB}$ & Rauvolfia vomitoria Afzel. & Apocynaceae & Leaves & Porto-novo & August 2020 \\
\hline YH $432 / \mathrm{HNB}$ & Senna italica Mill. & Leguminosae & Leaves & Tanguieta & July 2020 \\
\hline YH $439 / \mathrm{HNB}$ & Vernonia amygdalina Delile & Asteraceae & Leaves & Abomey-Calavi & July 2020 \\
\hline
\end{tabular}

temperature in the shade at the Research Unit in Applied Microbiology and Pharmacology of natural substances (URMAPha). After drying, they were then reduced to powder using a Retsch SM 2000/1430/Upm/Smf electric mill. From this powder, two types of extraction of each organ of the medicinal plants studied were carried out, following the methodology described by Klotoé et al. [31]. These were the aqueous extraction and the hydroethanolic extraction (50\% water-ethanol; v/v). Thus, fifty (50) grams of powder were macerated in $500 \mathrm{~mL}$ of solvent (water and water-ethanol). The mixture was stirred continuously for 72 hours at room temperature. The homogenate obtained was filtered three times on absorbent cotton and once on Whatman No. 1 filter paper. The filtrate obtained was then evaporated at a temperature of $40^{\circ} \mathrm{C}$ in an oven (drying oven) until a dry mass was obtained which represents the extract. The extracts thus produced were placed in the refrigerator at $4^{\circ} \mathrm{C}$ and put back into solution during the various tests.

2.5. Larval Cytotoxicity Test. The cytotoxic effect of the powders of the studied plants was evaluated on the Artemia salina larvae. The method described by Dougnon et al. [32] was adopted in this study. Artemia salina larvae were obtained by hatching $10 \mathrm{mg}$ of Artemia salina eggs placed under continuous agitation in $1 \mathrm{~L}$ of seawater for 72 hours. Dilution series of order 2 of a stock solution of plant powder with a concentration of $20 \mathrm{mg} / \mathrm{mL}$ were carried out in order to have an increasing scale of concentration. To $1 \mathrm{~mL}$ of each of these diluted solutions was added $1 \mathrm{~mL}$ of seawater containing 16 live larvae. A control solution without the extract was prepared under the same conditions. All solutions were incubated under agitation for 24 hours. Counting the number of dead larvae in each solution under an optical microscope produced a representative curve of the number of surviving larvae versus the concentration of the extract. The data (concentration-response) were log-transformed, and the $\mathrm{LC}_{50}$ (mean lethal concentrations) was determined. To assess the larval toxicity of the extract, the correlation grid associating the degree of toxicity to the $\mathrm{LC}_{50}$ proposed by Moshi et al. [33] was used. According to this grid, if the $\mathrm{LC}_{50}$ value is higher than $0.1 \mathrm{mg} / \mathrm{mL}$, the extract is declared nontoxic. If this value is between 0.1 and $0.5 \mathrm{mg} / \mathrm{mL}$, the extract is slightly toxic, and if the $\mathrm{LC}_{50}$ is less than $0.1 \mathrm{mg} /$ $\mathrm{mL}$, the extract is toxic.

2.6. Acute Toxicity Test. The rats were divided into lots according to their weight. Since the extracts were administered orally, the method described in OECD guideline 423, the acute toxicity class method, was adopted. Since the selected plant species are commonly used by the population and no major toxic effects were reported, a toxicity limit test with a single dose of $2000 \mathrm{mg} / \mathrm{kg}$ body weight was used. Twelve hours before the toxicity tests were conducted, the animals were deprived of food and water. After weighing the rats, 21 groups of three rats were assembled and treated (Table 2).

During the experiment, the animals were monitored and observed individually twice a day (morning and evening) over a period of 14 days. A data collection sheet was drawn up for each rat in order to collect possible signs of toxicity (skin and hair changes, the appearance of edema, walking backward, breathing difficulties, morbidity, and mortality). At the end of the treatment, the rats were deprived of food the last night before sampling. Blood samples (Day 0 and Day 14) were taken by puncture of the retroorbital sinus for all animals under ether anesthesia. The blood sample was collected in two types of tubes, one containing EDTA and the other without anticoagulant (dry tube). The samples from EDTA tubes were intended for hematological analysis. The dry tubes are centrifuged at $4000 \mathrm{rpm}$ for 10 minutes, and the resulting serum is stored at $-20^{\circ} \mathrm{C}$ for analysis of biochemical parameters. After sampling, two animals per lot were sacrificed under anesthesia with ether for the collection of organs such as the liver and kidney. These organs were rinsed with $0.9 \%$ saline and fixed in $10 \%$ buffered formalin.

\subsubsection{Hematological and Biochemical Examinations.} These examinations were performed at the Research Unit in Applied Microbiology and Pharmacology of natural substances (URMAPha). The hematological examinations included red and white blood cell counts, hemoglobin level, 
TABle 2: Treatment of constituted animal lots.

\begin{tabular}{|c|c|c|c|}
\hline Lots & Lot type & $\begin{array}{c}\text { Substances } \\
\text { administered }\end{array}$ & Medicinal plants \\
\hline 1 & Control & Distilled water & \\
\hline 2 & Test & Aqueous extract & $\begin{array}{c}\text { Anacardium } \\
\text { occidentale }\end{array}$ \\
\hline 3 & Test & Hydroethanolic extract & $\begin{array}{l}\text { Anacardium } \\
\text { occidentale }\end{array}$ \\
\hline 4 & Test & Aqueous extract & Daniellia oliveri \\
\hline 5 & Test & Hydroethanolic extract & Daniellia oliveri \\
\hline 6 & Test & Aqueous extract & Diospyros mespiliformis \\
\hline 7 & Test & Hydroethanolic extract & Diospyros mespiliformis \\
\hline 8 & Test & Aqueous extract & Manihot esculenta \\
\hline 9 & Test & Hydroethanolic extract & Manihot esculenta \\
\hline 10 & Test & Aqueous extract & Ocimum gratissimum \\
\hline 11 & Test & Hydroethanolic extract & Ocimum gratissimum \\
\hline 12 & Test & Aqueous extract & Khaya senegalensis \\
\hline 13 & Test & Hydroethanolic extract & Khaya senegalensis \\
\hline 14 & Test & Aqueous extract & Pterocarpus erinaceus \\
\hline 15 & Test & Hydroethanolic extract & Pterocarpus erinaceus \\
\hline 16 & Test & Aqueous extract & Rauvolfia vomitoria \\
\hline 17 & Test & Hydroethanolic extract & Rauvolfia vomitoria \\
\hline 18 & Test & Aqueous extract & Senna italica \\
\hline 19 & Test & Hydroethanolic extract & Senna italica \\
\hline 20 & Test & Aqueous extract & Vernonia amygdalina \\
\hline 21 & Test & Hydroethanolic extract & Vernonia amygdalina \\
\hline
\end{tabular}

hematocrit, Mean Globular Volume (MGV), Mean Corpuscular Hemoglobin Content $(\mathrm{MCH})$, and determination of Mean Corpuscular Hemoglobin Concentration (MCHC). The biochemical tests were concerned with the determination of urea, creatinine, aspartate aminotransferase (ASAT), and alanine aminotransferase (ALAT).

2.6.2. Histological Examinations. Histological sections of the liver and kidneys were performed at the histopathology Laboratory of the Institute of Applied Biomedical Sciences (ISBA) of the University of Abomey-Calavi. The pathomorphological study consisted of hematoxylin-eosin staining of thin sections of $5 \mu \mathrm{m}$ thicknesses. It is routine staining after which the nuclei, stained by hematoxylin, appear dark blue, and the cytoplasm, stained by eosin, appears pink. The microscopic observation of these sections was carried out with the ZEISS camera microscope at different magnifications so that only the most representative photographs were selected.

2.7. Data Analysis. The obtained data were subjected to statistical analysis using SPSS 26.0. Quantitative variables were presented as mean and standard deviation. Qualitative variables were presented in percentages. The probit analysis was used for the $\mathrm{LC}_{50}$ determination. The student test was used to compare the values of the different biochemical and hematological parameters of the treated animals with those of the control lot. The weight gain of the rats in each of the test lots was also compared to that of the control lot via Student's $t$-test. The significance threshold was set at $5 \%$.

\section{Results}

The data obtained in this study are related to the phytochemical screening of the studied plants, larval cytotoxicity, and the different parameters of acute toxicity.

3.1. Qualitative Phytochemical Analysis of the Studied Plants. Table 3 presents the results of the phytochemical screening of samples of the plants studied. From this table, it should be noted that the plants' extracts present a varied richness in secondary metabolites. Thus, we note the presence of tannins in all the samples of the plants studied with a strong presence in the powder of Vernonia amygdalina, Pterocarpus erinaceus, and Senna italica. As for flavonoids, which belong to the group of phenolic compounds in the same way as tannins, their presence was reported in all plants studied except Senna italica, Anacardium occidentale, and Manihot esculenta. Moreover, except Pterocarpus erinaceus, saponosides are identified in all plants studied. The same observation is made concerning the reducing compounds which were identified in all plants except Manihot esculenta. Alkaloids were detected in five of the ten plants studied. These are Khaya senegalensis, Ocimum gratissimum, Daniellia oliveri, Diospyros mespiliformis, and Vernonia amygdalina.

3.1.1. Larval Cytotoxicity. The sensitivity of Artemia Salina larvae of the different extracts of the plants studied is presented in Figure 1. It emerges increased mortality of Artemia Salina larvae as the concentration of extracts of the plants studied increases. $\mathrm{LC}_{50}$ obtained for the studied medicinal plants ranges from 0.02 to $1.93 \mathrm{mg} / \mathrm{mL}$ (Table 4). By reporting $\mathrm{LC}_{50}$ values obtained at the scale established by Moshi et al. [33], it appears that, at the concentrations tested, plants with $\mathrm{LC}_{50}$ values between 0.10 and $1.93 \mathrm{mg} / \mathrm{mL}$ are noncytotoxic $\left(\mathrm{LC}_{50} \geq 0.1 \mathrm{mg} / \mathrm{mL}\right)$. On the other hand, plants such as Senna italica and Daniellia oliveri have medium cytotoxicity $\left(0.05 \mathrm{mg} / \mathrm{mL}>\mathrm{LC}_{50} \geq 0.1 \mathrm{mg} / \mathrm{ml}\right)$.

\subsection{Acute Toxicity}

3.2.1. $L D_{50}$ of the Studied Plant Extracts. No mortality was noted in the animals of the different lots at the doses tested $(2000 \mathrm{mg} / \mathrm{kg})$. Similarly, no signs of apparent toxicity were observed. The $\mathrm{LD}_{50}$ of the studied plants is thus higher than $2000 \mathrm{mg} / \mathrm{kg}$.

3.2.2. Weight Change of Animals in Different Lots. Data collected on the body weight of the rats during the experiment are summarized in Table 5. From this table, a weight growth of the Wistar rats should be noted in all the groups. This weight growth was significant for the treated rats with Anacardium occidentale, Senna italica, and Manihot esculenta aqueous extract $(p<0.05)$.

The influence of the different treatments on the biochemical parameters of treated and control rats is summarized in Table 6. From this table, it appears that the plant extracts 
TABLE 3: Qualitative phytochemical screening of the studied medicinal plants.

\begin{tabular}{|c|c|c|c|c|c|c|c|c|c|c|c|}
\hline Secondary metabolites & Test reagents & $\mathrm{AO}$ & $\mathrm{DM}$ & DO & KS & $\mathrm{Me}$ & OG & $\mathrm{PE}$ & RV & SI & $\mathrm{VA}$ \\
\hline Tannins & Ferric chloride & + & + & + & + & + & + & ++ & + & ++ & ++ \\
\hline Catechic tannins & Stiasny's reagent & + & + & + & + & + & + & ++ & - & ++ & - \\
\hline Gallic tannins & Ferric chloride and saturation with sodium acetate & + & + & - & - & + & + & ++ & - & - & ++ \\
\hline Flavonoids & Shinoda test with powder magnesium & - & + & + & + & - & + & ++ & + & - & ++ \\
\hline Anthocyanins & Hydrochloric acid and ammonia at $50 \%$ & - & - & - & - & - & + & - & - & - & ++ \\
\hline Leuco-anthocyanins & Hydrochloric acid & + & + & + & + & - & - & - & - & - & - \\
\hline Alkaloids & Mayer's reagent & - & + & + & + & - & + & - & & - & ++ \\
\hline Mucilage & Absolute alcohol test & - & - & + & + & - & - & - & + & ++ & ++ \\
\hline Reducing compounds & Test with fehling liqueur & + & + & + & + & - & + & + & + & + & + \\
\hline Sterol-terpenes & Anhydride acetic-sulfuric acid & - & - & - & - & - & - & ++ & + & - & ++ \\
\hline Saponosides & Foam index test & + & + & + & + & + & + & - & + & + & + \\
\hline
\end{tabular}

+: presence; -: absence; ++: Strong presence. AO: Anacardium occidentale; DM: Diospyros mespiliformis; DO: Daniellia oliveri; KS: Khaya senegalensis; ME: Manihot esculenta; OG: Ocimum gratissimum; PE: Pterocarpus erinaceus; RV: Rauvolfia vomitoria; SI: Senna italica; VA: Vernonia amygdalina.
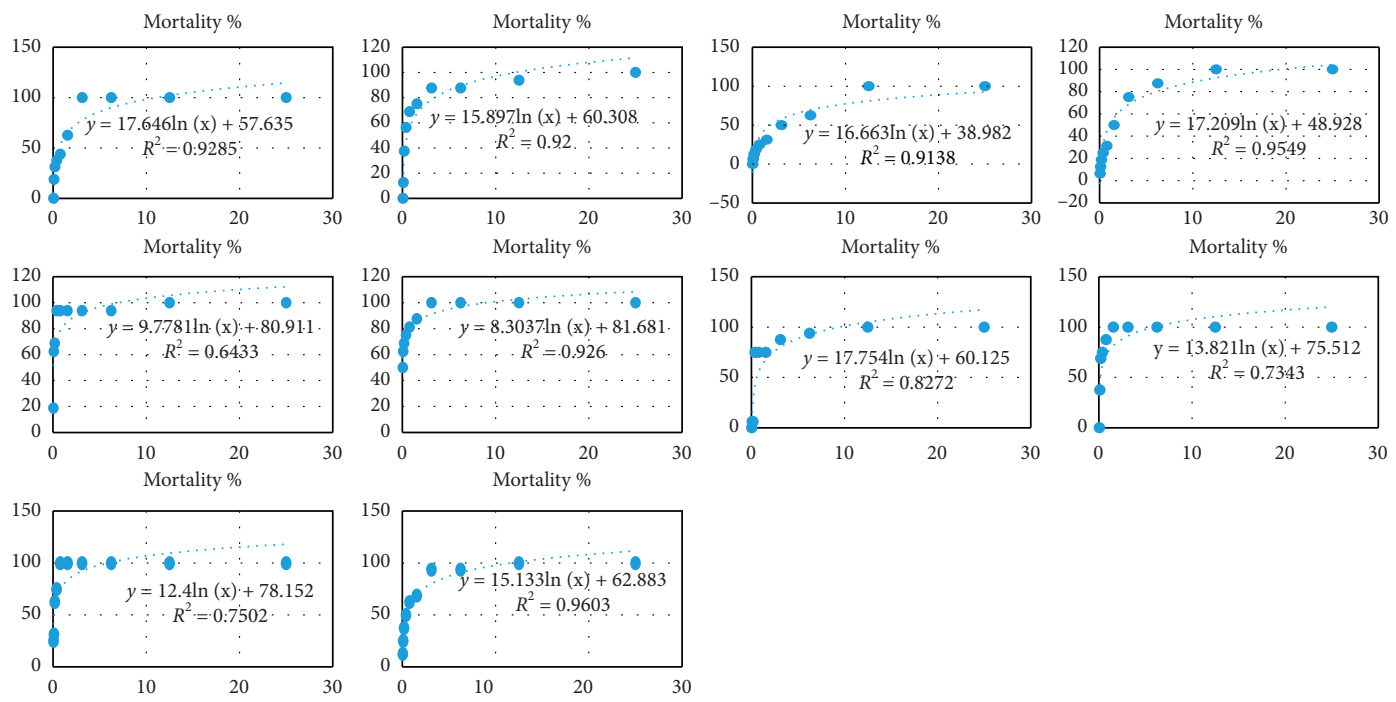

Figure 1: Sensitivity of Artemia Salina larvae to the studied medicinal plants.

TABLE 4: $\mathrm{LC}_{50}$ of the studied medicinal plants and their interpretation.

\begin{tabular}{lcc}
\hline Plants & $\mathrm{LC}_{50}(\mathrm{mg} / \mathrm{mL})$ & $\mathrm{R}^{2}$ \\
\hline Anacardium occidentale & 0.65 & 0.93 \\
Daniellia oliveri & 0.04 & 0.64 \\
Diospyros mespiliformis & 1.93 & 0.91 \\
Khaya senegalensis & 1.06 & 0.95 \\
Manihot esculenta & 0.52 & 0.92 \\
Ocimum gratissimum & 0.1 & 0.75 \\
Pterocarpus erinaceus & 0.15 & 0.73 \\
Rauvolfia vomitoria & 0.56 & 0.83 \\
Senna italica & 0.02 & 0.92 \\
Vernonia amygdalina & 0.43 & 0.96 \\
\hline
\end{tabular}

studied had no significant influence on the different biochemical parameters compared to the control group $(p>0.05)$. However, there was a significant decrease in ASAT levels in rats treated with the aqueous extract of Ocimum gratissimum $(p<0.05)$.
3.2.3. Effect of the Studied Plant Extracts on Hematological Parameters. Tables 7 and 8 present, respectively, the influence of the studied plants on the parameters of the erythrocytic and leukocytic lineages. Statistical analysis of the data presented in these tables shows that, compared to the Wistar rats in the control group, all the extracts of the ten plants studied have no significant effect on these different hematological parameters of the animals $(p>0.05)$.

3.2.4. Histopathology Study. From kidney and liver tissues, histological sections were performed to confirm the hematological and biochemical data. For all extracts, histological sections of the organs of treated rats show no structural abnormalities compared to controls. Figures 2 and 3 show, respectively, the hepatic and renal histology of extract-treated and control rats.

The hepatic parenchyma of treated rats (B) has a typical appearance as observed in control rats (A). The hepatocytes (arrows) have a normal appearance and are arranged in 
TABLE 5: Evolution of the body weight of the Wistar rats.

\begin{tabular}{|c|c|c|c|c|c|}
\hline \multirow{2}{*}{$\begin{array}{l}\text { Parameters } \\
\text { Plants }\end{array}$} & \multicolumn{5}{|c|}{ Rat weight } \\
\hline & Extracts & Day 0 & Day 14 & Gain/loss & Gain/loss (\%) \\
\hline Control & D. W & $137 \pm 5.29$ & $155.66 \pm 4.16$ & 18.67 & 13.62 \\
\hline \multirow{2}{*}{ Anacardium occidentale } & $\mathrm{H}_{2} \mathrm{O}$ & $131.33 \pm 5.13$ & $160.33 \pm 6.66$ & 29 & $22.08^{*}$ \\
\hline & $\mathrm{EtH}_{2} \mathrm{O}$ & $140.33 \pm 3.51$ & $124.67 \pm 5.03$ & 4.33 & 3.09 \\
\hline \multirow[t]{2}{*}{ Daniellia oliveri } & $\mathrm{H}_{2} \mathrm{O}$ & $132.33 \pm 4.73$ & $146.67 \pm 5.51$ & 14.33 & 10.83 \\
\hline & $\mathrm{EtH}_{2} \mathrm{O}$ & $139.67 \pm 8.08$ & $140.67 \pm 2.52$ & 1 & 0.716 \\
\hline \multirow[t]{2}{*}{ Diospyros mespiliformis } & $\mathrm{H}_{2} \mathrm{O}$ & $134.67 \pm 6.43$ & $136.33 \pm 3.78$ & 1.67 & 1.24 \\
\hline & $\mathrm{EtH}_{2} \mathrm{O}$ & $157 \pm 2$ & $155.67 \pm 8.50$ & 5.33 & 3.39 \\
\hline \multirow[t]{2}{*}{ Khaya senegalensis } & $\mathrm{H}_{2} \mathrm{O}$ & $147 \pm 6$ & $134.33 \pm 0.58$ & 4 & 2.72 \\
\hline & $\mathrm{EtH}_{2} \mathrm{O}$ & $135 \pm 3$ & $136 \pm 4$ & 1 & 0.74 \\
\hline \multirow[t]{2}{*}{ Manihot esculenta } & $\mathrm{H}_{2} \mathrm{O}$ & $134.33 \pm 3.79$ & $167 \pm 8.18$ & 32.67 & $24.32^{*}$ \\
\hline & $\mathrm{EtH}_{2} \mathrm{O}$ & $162.67 \pm 11.93$ & $172.67 \pm 4.16$ & 10 & 6.15 \\
\hline \multirow[t]{2}{*}{ Ocimum gratissimum } & $\mathrm{H}_{2} \mathrm{O}$ & $138 \pm 7.55$ & $124.67 \pm 10.69$ & 3.33 & 2.41 \\
\hline & $\mathrm{EtH}_{2} \mathrm{O}$ & $134 \pm 3.46$ & $134.33 \pm 6.03$ & 0.33 & 0.25 \\
\hline \multirow[t]{2}{*}{ Pterocarpus erinaceus } & $\mathrm{H}_{2} \mathrm{O}$ & $138.67 \pm 5.13$ & $149 \pm 7$ & 10.33 & 7.45 \\
\hline & $\mathrm{EtH}_{2} \mathrm{O}$ & $137.33 \pm 3.05$ & $141.33 \pm 5.03$ & 4 & 2.91 \\
\hline \multirow[t]{2}{*}{ Rauvolfia vomitoria } & $\mathrm{H}_{2} \mathrm{O}$ & $138 \pm 2.64$ & $154 \pm 9.16$ & 16 & 11.59 \\
\hline & $\mathrm{EtH}_{2} \mathrm{O}$ & $160 \pm 3.46$ & $132.67 \pm 1.53$ & 6 & 3.75 \\
\hline \multirow[t]{2}{*}{ Senna italica } & $\mathrm{H}_{2} \mathrm{O}$ & $135.33 \pm 2.51$ & $163 \pm 3.61$ & 27.67 & $20.44^{*}$ \\
\hline & $\mathrm{EtH}_{2} \mathrm{O}$ & $131.67 \pm 4.72$ & $147.67 \pm 6.81$ & 16 & 12.15 \\
\hline \multirow[t]{2}{*}{ Vernonia amygdalina } & $\mathrm{H}_{2} \mathrm{O}$ & $130 \pm 7.94$ & $140.33 \pm 4.73$ & 10.33 & 7.95 \\
\hline & $\mathrm{EtH}_{2} \mathrm{O}$ & $132 \pm 7.93$ & $131 \pm 6.56$ & 1.33 & 1.01 \\
\hline
\end{tabular}

$\mathrm{H}_{2} \mathrm{O}$ : aqueous extract; $\mathrm{EtH}_{2} \mathrm{O}$ : hydroethanolic extract; DW: distilled water. ${ }^{*}$ Significant difference with the control group $(p<0.05)$. 3.2.3. Effect of the Studied Plant Extracts on the Biochemical Parameters of Rats

cords separated by sinusoids (S). The sinusoids drain into the centrilobular vein $(\mathrm{V})$.

The renal parenchyma of treated rats (B) has the typical architecture observed in control rats (A). The glomeruli (G), proximal tubes (TP), distal tubes (TD), and collecting channels (CC) are well identifiable. The extracts, therefore, did not affect the renal structures in any way.

\section{Discussion}

The present study aimed to explore the composition in secondary metabolites and reveal the toxicological characteristics of ten plants of the Beninese flora used in the traditional treatment of diarrheal diseases.

The qualitative phytochemical screening of the plants studied revealed a varied richness in bioactive molecules. The presence of catechic tannins, gallic tannins, flavonoids, anthocyanins, and sterol-terpenes, alkaloids, saponosides, and reducing compounds were detected. Among these bioactive compounds, tannins are identified in all the plants studied. Similar observations are reported in the literature [34-39]. This presence of tannins as well as those of other identified bioactive molecules evokes the medicinal properties of the plants studied and their therapeutic uses in several pharmacopoeias. Indeed, plants containing tannins have astringent, hemostatic, antiseptic, and toning properties [40]. In addition, the tannins contained in medicinal plants are endowed with antimicrobial [41, 42], antiviral, anti-inflammatory, antihypertensive, antimutagenic, immunostimulant, and antitumor properties [43-45]. Several reports have documented the efficacy of tannins in the treatment of diarrheal diseases [46-48]. As for flavonoids, it has been reported that plant extracts, which are rich in flavonoids, have antimicrobial activity $[49,50]$. A study has shown that flavonoids associated with saponins isolated from Anacardium occidentale, one of the medicinal plants in this study, are useful in the treatment of diarrhea [51]. Alkaloids, one of the metabolites identified in this study, are nitrogenous organic substances with antibacterial and antifungal properties [52]. The above evidence supports the use of the plants studied in the treatment of many diseases including diarrheal diseases.

The safety of the plants was evaluated in vitro in the Artemia Salina model and by acute oral toxicity according to the OECD 423 protocol. The cytotoxic effect of the extracts evaluated according to the Artemia Salina model was used as a preliminary safety screening. The data obtained for this test indicate that, with the exception of Senna italica and Daniellia oliveri, all other plants studied are noncytotoxic to Artemia Salina larvae at the concentrations tested. Similar observations were reported by Dehou et al. [53] and Déguénon et al. [54] for Ocimum gratissimum and Soha et al. [55] for Khaya senegalensis. Lagarto Parra et al. [56] demonstrated a good correlation $(r=0.85 ; p<0.05)$ between this larval toxicity test and toxicological effects on a whole animal. Some authors have confirmed this hypothesis in their work [57-59]. However, such an extrapolation is hotly debated [60]. In order to confirm the data of this preliminary screening, on the one hand, and to explore the safety of the studied plants on a whole organism, on the other hand, the acute oral toxicity test in Wistar albino rats was carried out. The results obtained indicate that no mortality was recorded during the 14 days of the experiment. Similarly, no signs of apparent toxicity were observed. The plants studied thus 


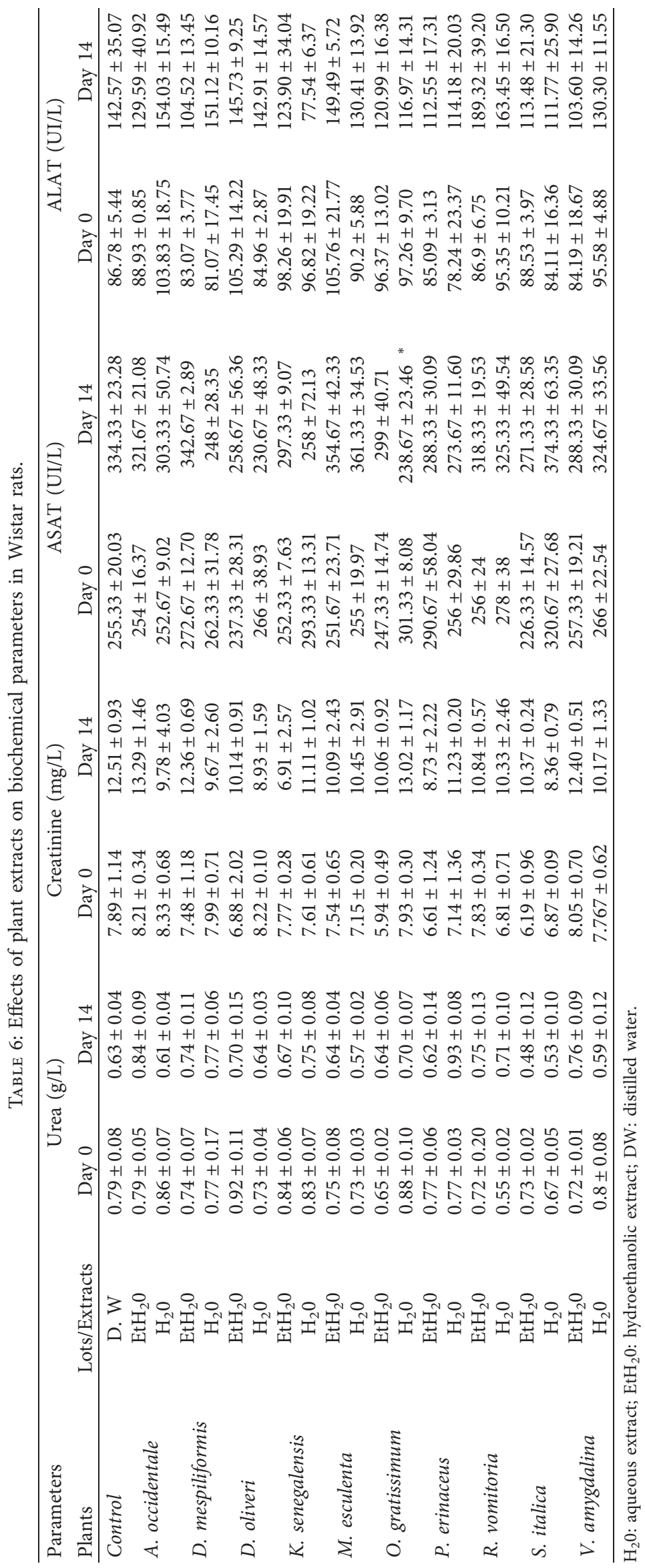




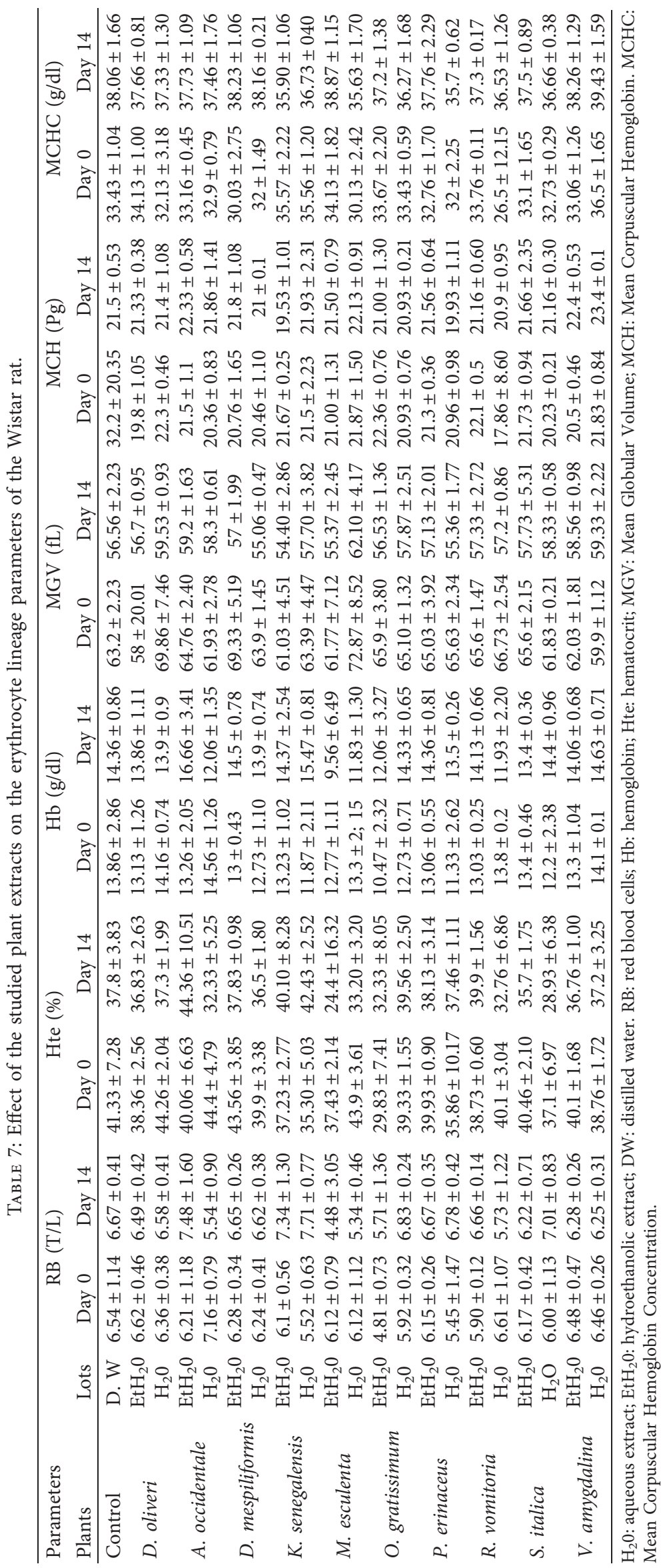


TABLE 8: Effect of the studied plant extracts on the leukocyte lineage parameters of the Wistar rat.

\begin{tabular}{|c|c|c|c|c|c|c|c|c|c|}
\hline \multicolumn{2}{|l|}{ Parameters } & \multicolumn{2}{|c|}{ White blood cell (G/L) } & \multicolumn{2}{|c|}{$\begin{array}{c}\text { Neutrophilic Polynuclear } \\
(\%)\end{array}$} & \multicolumn{2}{|c|}{ Monocytes (\%) } & \multicolumn{2}{|c|}{ Lymphocytes (\%) } \\
\hline Plants & Lots & Day 0 & Day 14 & Day 0 & Day 14 & Day 0 & $\mathrm{Da}$ & Day 0 & Day 14 \\
\hline Contro & D. W & 0607 & & 6820 & & & & & \\
\hline \multirow[t]{2}{*}{ D. oliveri } & $\mathrm{EtH}_{2} \mathrm{O}$ & & & & & & & & \\
\hline & & 25 & 6.83 & & & & & & \\
\hline \multirow[t]{2}{*}{ A. occidentale } & Et & & & & & & & & \\
\hline & & & & & & 6 & & 5 & \\
\hline \multirow[t]{2}{*}{ D. mespiliformis } & $\mathrm{EtH}_{2} \mathrm{O}$ & & & & & & & & \\
\hline & & & & & & & & & \\
\hline \multirow[t]{2}{*}{ K. senegalensis } & $\mathrm{EtH}_{2} \mathrm{O}$ & 56 & 6 & 5.00 & & & & 5 & \\
\hline & & 1.1 & & & & & & 0 & \\
\hline \multirow[t]{2}{*}{ M. esculenta } & $\mathrm{H}_{2} \mathrm{O}$ & & & & & 7 & & 0 & \\
\hline & & & & & & & & & \\
\hline \multirow[t]{2}{*}{ O. gratissimum } & $\mathrm{EtH}_{2} \mathrm{O}$ & 6.17 & & & & & & & \\
\hline & & & & & & & & 4 & \\
\hline \multirow[t]{2}{*}{ P. erinaceus } & $\mathrm{EtH}_{2} \mathrm{O}$ & $6.73 \pm$ & 7.9 & 2 & & 5. & 12. & 88.26 & 96 \\
\hline & & $4.96 \pm 0$ & 10.43 & & & $4.93=$ & & $91.23 \pm$ & \\
\hline \multirow[t]{2}{*}{ R. vomitoria } & $\mathrm{EtH}_{2} \mathrm{O}$ & $6.56 \pm 0.55$ & 8.86 & $9.66 \pm$ & 27. & 10.06 & 10.8 & $80.26 \pm$ & 61. \\
\hline & & & & & & & & & \\
\hline \multirow[t]{2}{*}{ S. italica } & $\mathrm{EtH}_{2} \mathrm{O}$ & $7.03 \pm$ & & & & $4.66 \pm$ & 0 & 87.86 & \pm 2.00 \\
\hline & & $9.83 \pm 2.59$ & $12.96 \pm 1.55$ & $6.77 \pm 2.06$ & $15.23 \pm 4$ & $6.76 \pm 1.32$ & $7.73 \pm$ & $86.46 \pm 3.12$ & $74.7 \pm 2.42$ \\
\hline \multirow[t]{2}{*}{ V. amygdalina } & $\mathrm{EtH}_{2} \mathrm{O}$ & $5.5 \pm 1.9$ & $9.8 \pm 2.16$ & $7.03 \pm 3.69$ & $24.7 \pm 5.30$ & $5.43 \pm 1.28$ & $12.66 \pm 2.11$ & $87.53 \pm 4.70$ & $62.63 \pm 6.74$ \\
\hline & $\mathrm{H}_{2} \mathrm{O}$ & $6.23 \pm 2.61$ & $6.2 \pm 1.91$ & $10.26 \pm 5.48$ & $21.36 \pm 2.45$ & $5.53 \pm 1.19$ & $11.4 \pm 2.6$ & $84.2 \pm 6.07$ & $67.23 \pm 4.30$ \\
\hline
\end{tabular}

$\mathrm{H}_{2} \mathrm{O}$ : aqueous extract; $\mathrm{EtH}_{2} \mathrm{O}$ : hydroethanolic extract; DW: distilled water.
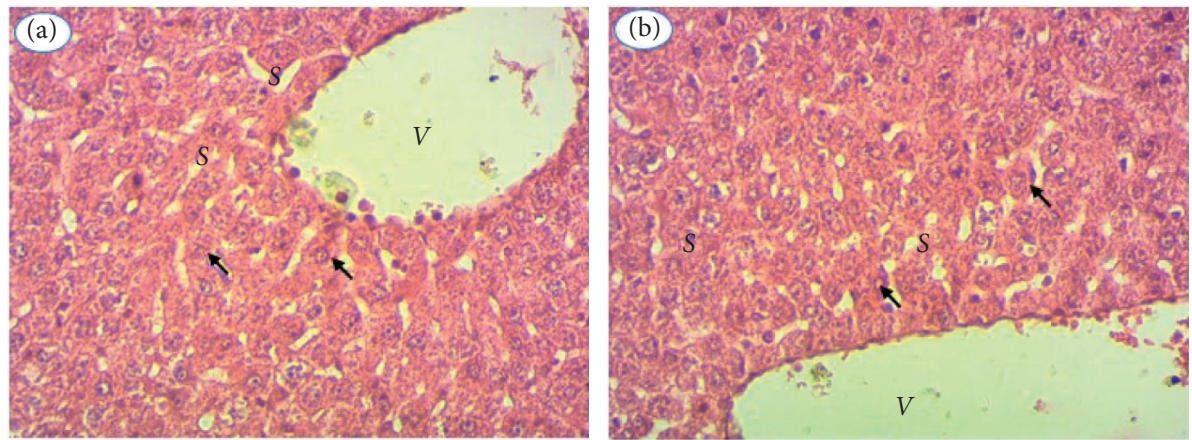

FIgURE 2: Hepatic histology of rats treated with extracts of the plants studied and control rats (A), 400x magnification.
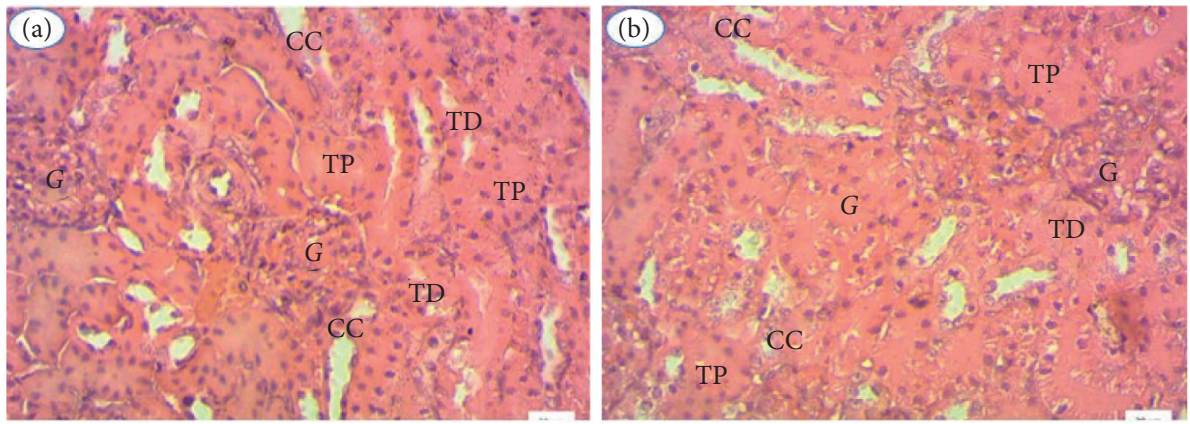

Figure 3: Kidney histology of rats treated with the plant extracts studied (B) and control rats (A), 400x magnification.

have an $\mathrm{LD}_{50}$ higher than $2000 \mathrm{mg} / \mathrm{kg}$. In the literature, it is reported that plants with an $\mathrm{LD}_{50}$ greater than $1000 \mathrm{mg} / \mathrm{kg}$ orally are considered nontoxic [61]. In addition, during the experiment, the evolution of the body weight of the animals was monitored. The data obtained for this parameter indicate weight growth in all animals' lots, reflecting their good 
physiological condition. This information suggests that the aqueous and hydroethanolic extracts of the ten plants studied show no apparent toxicity at the dose of $2000 \mathrm{mg} /$ $\mathrm{kg}$. Similar observations have been reported in the literature by several authors for different extracts of the plants studied. Indeed, Konan et al. [37] and Jintanaporn et al. [62] reported that, at $2000 \mathrm{mg} / \mathrm{kg}$, hydroethanolic extract from the leaves of Anacardium occidentale induced no mortality or signs of apparent toxicity. The same observation is reported by Ahmadu et al. [63] for the ethanolic extract of Daniellia oliveri. Ebbo et al. [64] demonstrated the safety of the methanolic extract of the leaves of Diospyros mespiliformis at a dose of $5000 \mathrm{mg} / \mathrm{kg}$ in Wistar rats. Nadro and Modibo [65] have also proven the safety of aqueous and ethanolic extracts of Senna italica in their work. As for Pterocarpus erinaceus, Ajayi et al. [34] showed that the ethanolic extract of the leaves of this plant induced no apparent toxicity in Wistar rats at a dose of $5000 \mathrm{mg} / \mathrm{kg}$.

The study of Nkoua Badzi et al. [38] reached the same conclusion with regard to the aqueous extract of Rauvolfia vomitoria. Legba et al. [66] showed the safety of aqueous and ethanolic extracts of the leaves of Vernonia amygdalina used in Southern Benin. Ojo et al. [40] and Satish and Ranjana [67] reported the safety of ethanolic aqueous extracts of the leaves of Manihot esculenta and Ocimum gratissimum, respectively. For Khaya senegalensis, the data obtained from this study are consistent with those reported by Soha et al. [55].

Beyond the data on the apparent toxicity of medicinal plants, adverse effects can be observed at the tissue scale through functional and structural alterations of certain vital organs such as the liver and kidneys. These aspects were taken into account in the present study by exploring renal, hepatic, and hematological parameters as well as a histopathological study of these organs. The exploration of the hepatic function concerned the measurement of the enzymatic activity of transaminases (ASAT, ALAT). ALAT and ASAT are the main markers of liver function generally explored in toxicological studies of medicinal plants. Under normal physiological conditions, these markers are present at low concentrations in serum. Elevated serum levels of these enzymes, particularly ALAT, are considered sensitive markers of liver damage $[68,69]$. In this study, no significant influence was noticed on the activity of these enzymes. However, it is reported that the nonsignificant increase in the levels of these enzymes observed in both the test and control lots is not related to any functional impairment of the liver but rather to stress due to manipulation. This hypothesis is reinforced by the histopathological study which revealed that no structural alterations of the liver were observed.

The renal parameters evaluated in the exploration of kidney function were uremia and creatininemia. Any increase in the level of these markers indicates probable kidney tissue damage [70]. In this study, it should be noted that no significant effect was induced by the treatments with the various plant extracts studied. These data, which reflect an absence of functional alteration of the kidneys, are reinforced by the histological study which revealed an absence of structural alteration of this organ.

Moreover, the hematopoietic system is one of the most sensitive targets for toxic substances [71]. It represents an important marker of the physiological and pathological state of humans and animals. Any alteration in hematological parameters is perceived as a potential risk of anemia [72]. Data from the present study indicate that the plants studied had no significant effect on either erythrocyte or leukocyte lineage parameters. This suggests that the extracts of the ten plants studied were not responsible for any anemic disorders. However, the increase in the number of leukocyte lineage cells (white blood cells and monocytes) observed could be explained by the fact that there was a possible thrombocytosis coupled with hyperleukocytosis. This could be attributed to the use of the metallic gastric tube. Dougnon et al. [73] support this idea by reporting that since the test lots were force-fed and the control batch had free access to water, it is possible that the probe may have attacked the esophageal wall of these animals causing an acute syndrome.

From the abovementioned data, it appears that the different extracts of the studied plants were not responsible for any mortality and any alteration of biochemical and hematological parameters. They do not present any risk of toxicity when used at a dose of $2000 \mathrm{mg} / \mathrm{kg}$.

\section{Conclusion}

The purpose of this study was to generate recent data on the phytochemical and toxicological characteristics of ten (10) plants used in the traditional treatment of diarrheal diseases. Phytochemical screening of the plants studied revealed a varied richness of secondary metabolites. Two approaches were adopted for safety testing: acute oral toxicity and larval cytotoxicity. The results obtained following the larval cytotoxicity model indicated that the plants studied are noncytotoxic. Acute toxicity data indicate that the plants studied did not induce mortality or structural and functional alterations of the liver and kidneys at the dose of $2000 \mathrm{mg} / \mathrm{kg}$. These observations justify the use of these plants in several African pharmacopeias. However, more in-depth toxicological studies (subacute, chronic, and subchronic toxicity) are necessary for a better knowledge of the toxicological profile of these plants.

\section{Data Availability}

The data used to support the findings of this study are fully available upon request from the corresponding author.

\section{Ethical Approval}

The Benin National Ethical Committee for Health Research has reviewed and approved this study (65/MS/DC/SGM/ DRFMT/CNERS/SA). Moreover, this study received ethical approval from the Ethical Committee of the Research Unit in Applied Microbiology and Pharmacology of Natural Substances (035-19/URMAPHA/EPAC/UAC). 


\section{Conflicts of Interest}

The authors declare that they have no conflicts of interest.

\section{Authors' Contributions}

Kafayath Fabiyi is a co-author of this manuscript.

\section{Acknowledgments}

The authors are very grateful to Dr. Jerrold Agbankpe and M. Arnaud Soha for their contributions during the implementation of this study. The authors are very grateful to the World Academy of Sciences (TWAS) and the United Nations Educational, Scientific and Cultural Organization (UNESCO). These two institutions have made this research possible through research funding allocated to the research team under the TWAS Research Grant Award_20-254 RG/ BIO/AF/AC_G. They thank the Program SEEDING LABS which reinforced the technical platform of the Research Unit in Applied Microbiology and Pharmacology of Natural Substances at the University of Abomey-Calavi (Benin).

\section{References}

[1] V. Kimpouni, M.-Y. Lenga-Sacadura, J. C. Mamboueni, and E. N. Mikoko, "Phytodiversite et pharmacopée traditionnelle de La communauté kaamba de madingou (bouenza-congo)," European Scientific Journal, ESJ, vol. 14, no. 3, pp. 191-220, 2018.

[2] K. O. Moussaouil Ahmed HedjalaG. Zitouni et al., "Estimation de la toxicité des d'huiles essentielles formulées de thym et d'eucalyptus et d'un produit de synthèse sur le parasite de l'abeille tellienne varroa destructor (arachnida, varroidae)," Agobiologia, vol. 4, no. 1, pp. 17-26, 2014.

[3] J. M.-A. S. Ouachinou, A. C. Adomou, G. H. Dassou, H. Yedomonhan, G. M. Tossou, and A. Akoegninou, "Connaissances et pratiques ethnobotaniques en médecines traditionnelles vétérinaire et humaine au Bénin: similarité ou dissemblance ?" Journal of Applied Biosciences, vol. 113, no. 1, pp. 11174-11183, 2017.

[4] Y. Hoekou, K. Batawila, K. Gbogbo et al., "Evaluation des propriétés antimicrobiennes de quatre plantes de la flore togolaise utilisées en médecine traditionnelle dans le traitement des diarrhées infantiles," International Journal Biological Chemical Sciences, vol. 6, no. 6, pp. 3089-3097, 2013.

[5] J. Klotoé, T. V. Dougnon, J. Ategbo et al., "Ethnopharmacological survey on antihemorrhagic medicinal plants in South of Benin," European Journal of Medicinal Plants, vol. 3, no. 1, pp. 40-51, 2013.

[6] E. E. Bafor, "Potentiels d'utilisation des plantes médicinales dans les troubles de la reproduction chez la femme - La voie à suivre," African Journal of Reproductive Health, vol. 21, no. 4, pp. 12-16, 2017.

[7] J.-Y. Chabrier, "Plantes médicinales et formes d'utilisation en phytothérapie," Sciences Pharmaceutiques, vol. 184, 2010.

[8] S. Collins, X. Martins, A. Mitchell, A. Teshome, and J. T. Arnason, "Quantitative ethnobotany of two east Timorese cultures," Economic Botany, vol. 60, no. 4, pp. 347-361, 2006.

[9] S. Molares and A. Ladio, "Ethnobotanical review of the Mapuche medicinal flora: use patterns on a regional scale,"
Journal of Ethnopharmacology, vol. 122, no. 2, pp. 251-260, 2009.

[10] World Health Organization, Diarrhoeal Disease Fact Sheet, pp. 1-4, World Health Organization Media Center, Geneva, Switzerland, 2017.

[11] H. U. Ugboko, O. C. Nwinyi, S. U. Oranusi et al., "Childhood diarrhoeal diseases in developing countries," Heliyon, vol. 6, no. $4,2020$.

[12] Unicef, Committing to Child Survival: A Promise Renewed, Unicef, New York, NY, USA, 2013.

[13] S. Pande, M. Keyzer, A. Arouna et al., "Addressing diarrhea prevalence in the West African Middle Belt: Social and geographic dimensions in a case study for Benin," International Journal of Health Geographics, vol. 7, no. 17, 2008.

[14] J. M. M. Agbla, A. Capo-Chichi, A. J. Agbankpé et al., "Epidemiological survey of rotaviruses responsible for infantile diarrhea by the immunomolecular technique in cotonou (Benin, West Africa)," International Journal of Microbiology, vol. 2018, Article ID e3602967, 2018.

[15] WSP-ESI-Benin, Impacts économiques d'un mauvais assainissement en afrique, pp. 1-6, WSP-ESI-Benin, Porto-Novo, Benin, 2012.

[16] F. Djague, P. K. Lunga, K. R. M. Toghueo et al., "Garcinia kola (Heckel) and alchornea cordifolia (schumach. \& thonn.) Müll. arg. from cameroon possess potential antisalmonellal and antioxidant properties," PLoS One, vol. 15, no. 8, 2020.

[17] WHO, Statistiques Sanitaires Mondiales, World Health Organization, Geneva, Switzerland, 2011.

[18] A. Agbankpe, T. Dougnon, H. Bankole et al., "Etude ethnobotanique des légumes feuilles thérapeutiques utilisés dans le traitement des diarrhées au sud-Bénin (Afrique de l'Ouest)," International Journal of Biological and Chemical Sciences, vol. 8, no. 4, pp. 1784-1795, 2015.

[19] A. S. A. Ambe, D. Ouattara, M.-S. Tiebre et al., "Diversité des plantes médicinales utilisées dans le traitement traditionnel de la diarrhée sur les marchés d'Abidjan (Côte d'Ivoire)," Journal of Animal \& Plant Sciences, vol. 26, no. 16, pp. 4081-4096, 2015.

[20] H. Koudokpon, T. V. Dougnon, H. S. Bankolé et al., "Enquête Ethnobotanique sur les Plantes Utilisées dans le Traitement des Infections au Sud-Bénin," The Journal of Medicine and Health Sciences, vol. 18, no. 2, pp. 92-99, 2017.

[21] A. Akoegninou, W. J. Van der Burg, and L. L. O Van der Maesen, Flore analytique du Bénin, p. 1034, Backhuys, Publishers, Wageningen, Pays-Bas, 2006.

[22] B. O Fachola, G. Houéhanou, F. Gbesso et al., "Connaissances ethnobotaniques de parkia biglobosa (jacq.) r. br. ex g. don, de Daniellia oliveri (rolfe) hutch. et de uvaria chamae p. beauv. chez les populations locales du département du plateau au bénin," Revue Ivoirienne des Sciences et Technologie, vol. 32, no. 2018, pp. 315-330, 2018.

[23] N. Fofié, K. Yao, K. Traoré-koné et al., "Évaluation des activités antioxydante et antihyperglycémiante des feuilles de ocimum gratissimum 1. (lamiaceae)," Reb-Pasres, vol. 2, no. 2, pp. 19-30, 2017.

[24] O. Kolawole, "Anti-hyperglycemic effect of Khaya senegalensis stem bark aqueous extract in wistar rats," European Journal of Medicinal Plants, vol. 2, no. 1, pp. 66-73, 2012.

[25] E. Mpondo Mpondo, J. P. Ngene, L. Mpounze Som et al., "Connaissances et usages traditionnels des plantes médicinales du département du haut Nyong," Journal of Applied Biosciences, vol. 113, no. 1, Article ID 11229, 2017. 
[26] K. Y. Alain, A. D. P. Cokou, B. Diane et al., "Métabolites secondaires et activités biologiques des extraits de l'écorce de tronc de Khaya senegalensis, une plante à usage vétérinaire récoltée au Bénin," International Journal of Innovation and Applied Studies, vol. 23, pp. 441-450, 2018.

[27] OCDE_407, Test No. 407: Repeated Dose 28-day Oral Toxicity Study in Rodents, OECD, Paris, France, 2008.

[28] OCDE_423, Test No. 423: Acute Oral Toxicity - Acute Toxic Class Method, OECD, Paris, France, 2002.

[29] National Research Council, Guide for the Care and Use of Laboratory Animals, National Academies Press (US), Washington, DC, USA, 2011, http://www.ncbi.nlm.nih.gov/ books/NBK54050/, 8th edition.

[30] P. J. Houghton and A. Raman, Laboratory Handbook for the Fractionation of Natural Extracts, pp. 154-162, Thomson Publishing, Stamford, CT, USA, 1998.

[31] J. R. Klotoé, E. Agbodjento, V. T. Dougnon et al., "Exploration of the chemical potential and antioxidant activity of some plants used in the treatment of male infertility in southern Benin," Journal of Pharmaceutical Research International, vol. 32, pp. 1-12, 2020.

[32] T. Dougnon, H. Bankolé, P. Edorh et al., "Cytotoxicity of leaves and fruits of solanum macrocarpon linn (solanaceae) against shrimp larvae (artemia salina leach)," Research Journal of Recent Sciences, vol. 2, no. 5, pp. 6-9, 2013.

[33] M. J. Moshi, J. C. Cosam, Z. H. Mbwambo, M. Kapingu, and M. H. H. Nkunya, "Testing beyond ethnomedical claims: brine shrimp lethality of some tanzanian plants," Pharmaceutical Biology, vol. 42, no. 7, pp. 547-551, 2004.

[34] V. F. Ajayi, M. O. Uguru, D. Suleiman et al., "Antidiabetic effect of methalonic leaf extract of pterocarpus erinaceus in streptozotocin induced diabetic rats," Scientific Research Journal, vol. 6, 2017.

[35] M. Aliyu and B. Chedi, "Effects of the ethanolic stem bark extract of pterocarpus erinaceus poir (fabaceae) on some isolated smooth muscles," Bayero Journal Pure Applied Sciences, vol. 3, no. 1, pp. 34-38, 2010.

[36] O. A. Fabiyi, "Characterization, phytochemical analysis and nematicidal activity of Daniellia oliveri leaves against Meloidogyne incognita," Pakistan Journal of Nematology, vol. 32, no. 1, pp. 91-100, 2014.

[37] N. A. Konan, E. M. Bacchi, N. Lincopan, S. D. Varela, and E. A. Varanda, "Acute, subacute toxicity and genotoxic effect of a hydroethanolic extract of the cashew (Anacardium occidentale L.)," Journal of Ethnopharmacology, vol. 110, no. 1, pp. 30-38, 2007.

[38] C. Nkoua Badzi, D. Tano Konan, T. Dable Marius et al., "Antiplasmodial activity and acute oral toxicity of Rauvolfia vomitoria leaves extracts," International Journal of Pharmacological Research, vol. 08, no. 7, pp. 56-62, 2018.

[39] O. A. Ojo, O. I. Oloyede, O. I. Olarewaju et al., "Toxicity studies of the crude aqueous leaves extracts of ocimum gratissimum in albino rats," Iosr-jestft, vol. 6, pp. 34-39, 2013.

[40] K.-T. Chung, T. Y. Wong, C.-I. Wei, Y.-W. Huang, and Y. Lin, "Tannins and human health: a review," Critical Reviews in Food Science and Nutrition, vol. 38, no. 6, pp. 421-464, 1998.

[41] L. M. Redondo, P. A. Chacana, J. E. Dominguez et al., "Perspectives in the use of tannins as alternative to antimicrobial growth promoter factors in poultry," Frontiers Microbiology, vol. 5, 2014.

[42] A. Scalbert, "Antimicrobial properties of tannins," Phytochemistry, vol. 30, no. 12, pp. 3875-3883, 1991.

[43] K. S. Feldman, K. Sahasrabudhe, R. S. Smith, and W. J. Scheuchenzuber, "Immunostimulation by plant polyphenols: a relationship between tumor necrosis factor- $\alpha$ production and tannin structure," Bioorganic \& Medicinal Chemistry Letters, vol. 9, no. 7, pp. 985-990, 1999.

[44] H. Kolodzeij, O. Kayser, K. P. Latté, and D Ferreira, "Evaluation of the antimicrobial potency of tannins and related compounds using the microdilution broth method," Planta Medica, vol. 65, no. 5, pp. 444-446, 1999.

[45] T. Yoshida, T. Chou, T. Shingu, and T. Okuda, "Oenotheins $\mathrm{D}, \mathrm{F}$ and $\mathrm{G}$, hydrolysable tannin dimers from Oenothera laciniata," Phytochemistry, vol. 40, no. 2, pp. 555-561, 1995.

[46] C. Liu, Y. Zheng, W. Xu et al., "Rhubarb tannins extract inhibits the expression of aquaporins 2 and 3 in magnesium sulphate-induced diarrhoea model," BioMed Research International, vol. 2014, Article ID e619465, , 2014.

[47] A. Ren, W. Zhang, H. G. Thomas et al., "A tannic acid-based medical food, cesinex, exhibits broad-spectrum antidiarrheal properties: a mechanistic and clinical study," Digestive Diseases and Sciences, vol. 57, no. 1, pp. 99-108, 2012.

[48] M. Russo, V. Coppola, E. Giannetti et al., "Oral administration of tannins and flavonoids in children with acute diarrhea: a pilot, randomized, control-case study," Italian Journal of Pediatrics, vol. 44, p. 64, 2018.

[49] T. P. T. Cushnie and A. J. Lamb, "Antimicrobial activity of flavonoids," International Journal of Antimicrobial Agents, vol. 26, no. 5, pp. 343-356, 2005.

[50] D. Tungmunnithum, A. Thongboonyou, A. Pholboon, and A. Yangsabai, "Flavonoids and other phenolic compounds from medicinal plants for pharmaceutical and medical aspects: an overview," Medicines, vol. 5, no. 3, p. 93, 2018.

[51] K. Abubakar, M. Abubakar, C. Ugwah-Oguejiofor et al., "Antidiarrhoel activity of the saponin and flavonoid fractions of Anarcadium occidentale leaves in albino rats," Advancement in Medicinal Plant Research, vol. 3, no. 1, pp. 23-28, 2015.

[52] K. Patel, M. Gadewar, R. Tripathi, S. Prasad, and D. K. Patel, "A review on medicinal importance, pharmacological activity and bioanalytical aspects of beta-carboline alkaloid "Harmine"' Asian Pacific Journal of Tropical Biomedicine, vol. 2, no. 8, pp. 660-664, 2012.

[53] R. Dehou, V. Dougnon, P. Atchade et al., "Étude phytochimique et toxicologique de cassia italica, momordica balsamina et ocimum gratissimum, trois plantes utilisees contre la gale au sud-bénin," Revue Ivoirienne des Sciences et Technologie, vol. 13, 2018.

[54] E. Deguenon, T. Dougnon, M. Senou et al., "Biological and chemical activities of some beninese plant's extracts," International Journal of Biology, Pharmacy and Allied Science, vol. 6, no. 12, pp. 2333-2358, 2017.

[55] S. Soha, T. V. Dougnon, O. F. H. Ohouko et al., "Larval cytotoxicity and acute oral toxicity of aqueous extracts of Elaeis guineensis leaves and Khaya senegalensis stem bark in wistar rats," International Journal of Advanced Research, vol. 9, no. 9, pp. 573-584, 2019.

[56] A. L. Parra, R. Yhebra, I. Sardiñas et al., "Comparative study of the assay of Artemia salina L. and the estimate of the medium lethal dose (LD50 value) in mice, to determine oral acute toxicity of plant extracts," Phytomedicine: International Journal of Phytotherapy and Phytopharmacology, vol. 8, no. 5, pp. 395-400, 2001.

[57] J. L. Carballo, Z. L. Hernández-Inda, P. Pérez et al., “A comparison between two brine shrimp assays to detect in vitro cytotoxicity in marine natural products," BMC Biotechnology, vol. 2, no. 5, pp. 1-5, 2002. 
[58] O. O. Ogbole, P. A. Segun, and A. J. Adeniji, "In vitro cytotoxic activity of medicinal plants from Nigeria ethnomedicine on Rhabdomyosarcoma cancer cell line and HPLC analysis of active extracts," BMC Complementary Medicine and Therapies, vol. 17, no. 1, pp. 1-10, 2017.

[59] M. Pelka, C. Danzl, W. Distler, and A. Petschelt, "A new screening test for toxicity testing of dental materials," Journal of Dentistry, vol. 28, no. 5, pp. 341-345, 2000.

[60] S. Sánchez-Fortún, F. Sanz, A. Santa-María et al., "Acute sensitivity of three age classes of Artemia salina larvae to seven chlorinated solvents," Bulletin of Environmental Contamination and Toxicology, vol. 59, no. 3, pp. 445-451, 1997.

[61] E. C. G. Clarke and M. L. Clarke, Veterinary Toxicology, pp. 268-277, Cassel and Collier Macmillan Publishers, London, UK, 1977.

[62] W. Jintanaporn, W. Panakaporn, M. Supaporn et al., "Toxicity evaluation of Anacardium occidentale, the potential aphrodisiac herb," BioMed Research International, vol. 2019, pp. 1-20, 2019.

[63] A. Ahmadu, H. A. Kaita, M. Garba et al., "Antispasmodic actions of the leaves of Daniellia oliveri," Nigerian Journal of Natural Products and Medicine, vol. 7, pp. 13-15, 2003.

[64] A. A. Ebbo, D. Sani, M. M. Suleiman, A. Ahmad, and A. Z. Hassan, "Acute and sub-chronic toxicity evaluation of the crude methanolic extract of Diospyros mespiliformis hochst ex a. Dc (ebenaceae) and its fractions," Toxicology Reports, vol. 7, pp. 1138-1144, 2020.

[65] M. S. Nadro and A. A. Modibbo, "Effects of pterocarpus erinaceus stem bark aqueous extract on anemic rats," Scientific Research Journal (Scrip), vol. 2, no. 5, pp. 1-5, 2014.

[66] B. Legba, V. Dougnon, E. Deguenon et al., "Toxicological characterization of six plants of the beninese pharmacopoeia used in the treatment of salmonellosis," Journal of Toxicology, vol. 201912 pages, 2019.

[67] E. B. Satish and S. K. Ranjana, "Antidiarrheal activity of ethanolic extract of Manihot esculenta Crantz leaves in Wistar rats," Journal of Ayurveda and Integrative Medicine, vol. 6, pp. 35-40, 2015.

[68] D. E. Amacher, "A toxicologist's guide to biomarkers of hepatic response," Human \& Experimental Toxicology, vol. 21, no. 5, pp. 253-262, 2002.

[69] S. K. Ramaiah, "A toxicologist guide to the diagnostic interpretation of hepatic biochemical parameters," Food and Chemical Toxicology, vol. 45, no. 9, pp. 1551-1557, 2007.

[70] Y. Yuliandra, A. Armenia, A. N. Salaa, and F. Ismed, "Uji toksisitas subkronis ekstrak etanol tali putri (cassytha filiformis L.) terhadap fungsi ginjal tikus," Jurnal Sains Farmasi \& Klinis, vol. 2, no. 1, pp. 54-59, 2015.

[71] P. MandaO. M. M. O. Vangah -Manda et al., "Etude des toxicités aigue et subaiguë du remède nature utilise dans le traitement du paludisme," Revue Ivoirienne des Sciences et Technologie, vol. 29, pp. 145-458, 2017.

[72] J. T. Mukinda and J. A. Syce, "Acute and chronic toxicity of the aqueous extract of Artemisia afra in rodents," Journal of Ethnopharmacology, vol. 112, no. 1, pp. 138-144, 2007.

[73] V. Dougnon, H. Bankolé, P. Edorh et al., "Acute toxicity of solanum macrocarpon linn (solanaceae) on wistar rats: study about leaves and fruits," American Journal of Biochemistry, vol. 3, no. 3, pp. 84-88, 2013. 